Monika Noworolnik-Mastalska

Dolnośląska Szkoła Wyższa we Wrocławiu

\title{
Demokracja i uczenie się w miejscu pracy
}

Celem niniejszego artykułu jest refleksja nad relacjami zachodzącymi między uwarunkowaniami środowiska pracy współczesnych przedsiębiorstw, jako potencjalnego środowiska edukacyjnego, a możliwościami uczenia się partycypowania w miejscu pracy zgodnie z wartościami demokratycznymi.

Swoje rozważania rozpocznę od zastanowienia się nad szerszym problemem, który dotyczy dostrzeganego obecnie silnego związku edukacji i neoliberalizmu, tym samym włączając się w krytyczny dyskurs wokół tego zagadnienia. „Zderzenie" ze sobą tych dwóch sprzecznych ontologii (edukacji i neoliberalizmu) stwarza po pierwsze sposobność do podjęcia dyskusji nad ich nie problematycznym łączeniem w praktyce społecznej, po drugie zaś otwiera przestrzeń dla ukazania powstałych w wyniku tego „zderzenia” pęknięć. Obecnie nauczanie i uczenie się jest bardzo mocno osadzone w rozmaitych polityczno-ekonomicznych kontekstach. W związku z tym pojawia się pytanie o humanistyczne założenia edukacji. Jakie tak naprawdę cele realizuje i komu w istocie służy? Przy czym to krytyczne spojrzenie ma na celu nie tylko rozpoznanie w edukacji narzędzia uprawomocniania i utrwalania istniejącej, neoliberalnej ideologii, ale przede wszystkim ma stworzyć szansę dla zmiany istniejącego porządku. Chodzi tutaj o taką zmianę, która zmierza w stronę uczenia się postaw obywatelskich oraz zdobywania demokratycznej świadomości żyjących w obecnej rzeczywistości ludzi. Edukacja powinna być widziana inaczej. Zgodnie z wartościami demokracji powinna być zaangażowana $\mathrm{w}$ transformację na rzecz społeczeństwa i skutecznie przeciwdziałać nierównościom oraz praktykom wykluczania. Przede wszystkim powinna być świadoma swoich politycznych czy ekonomicznych założeń.

Przejdę teraz do ukazania odmienności w rozumieniu podstawowych wartości istotnych dla demokracji i neoliberalizmu, by zwrócić uwagę czytelnika na różnicę występującą pomiędzy edukacją dla demokracji i edukacją będącą na usługach neoliberalizmu. Kluczową sprawą jest uświadomienie sobie tych choć z pozoru ukrytych, to jednak fundamentalnych sprzeczności. 


\section{Wolność, równość i sfera publiczna - przestrzenie dyferencjacji neoliberalizmu i demokracji}

Jedną z podstawowych zasad doktryny neoliberalnej jest wolność, ale zredukowana do wolności ekonomicznej, tzw. wolności rynkowej. Dyskurs „wolnego rynku” staje się narzędziem ideologicznym, które nie tylko legitymizuje kapitalistyczne instytucje, ale i w określony sposób definiuje rzeczywistość ${ }^{1}$. W ten sposób zapoczątkowany proces urynkowienia stopniowo kolonizuje świadomość jego użytkowników, dlatego obserwowana jest raczej reprodukcja zastanego porządku społecznego, niż wyzwalanie się spod niego. Przy czym ta niczym nie ograniczana wolność jednostki, polegająca na prawie wyboru i realizacji własnych, indywidualnie obranych celów, może być osiągana nawet mimo kosztów ponoszonych przez pozostałe jednostki, czy nawet przez całe społeczeństwo. Największą wartością polityczną jest bezgraniczna wolność, tzw. „wolność od”, a nie demokracja, która wiąże się z zaangażowaniem i z odpowiedzialnością za swoje wybory, czyli z wolnością rozumianą jako „wolność do”. Innym postulatem jest przyznanie pełni równych praw wszystkim jednostkom. Człowiek zdolny jest sam o sobie stanowić i być za siebie w pełni odpowiedzialny, dlatego też ma prawo do własności i samoposiadania. Tutaj jednak mamy do czynienia z „mitem” owej równości, gdyż ta nadrzędna zasada demokratyczna przesuwa się zatem z rzeczywistej równości uprawnień i odpowiedzialności społecznych do szans na równość wobec posiadania przedmiotów ${ }^{2}$. Jest to demokracja statusu ${ }^{3}$, a tzw. „ekonomiczna sprawiedliwość” opiera się tylko na „równości zasobów”. Związek łączący kapitalizm z demokracją jest wątły, gdyż pierwszy z nich służy interesom prywatnym, a drugi interesom publicznym, a jak wiadomo, są to interesy rozbieżne. W zamian dostrzegalna jest bezkrytyczna afirmacja różnicy i zgoda na narastające nierówności, które dodatkowo pogłębia edukacja. Neoliberalna kultura stawia rynek przed społeczeństwem. Stosuje mechanizmy przejawiające się w posługiwaniu się populistyczną argumentacją i manipulacją hasłami o wolnym wyborze, niezależności i prawych rządach. Proces silnego zubożenia sfery publicznej i widoczne osłabienie ducha obywatelskości jest wynikiem specyficznego pojmowania sfery obywatelskiej w neoliberalizmie. Społeczeństwo obywatelskie wyraża się tutaj poprzez autonomiczne decyzje swoich członków ${ }^{4}$. Ma sens, dopóki służy realizacji jakichś interesów, jednak samo w sobie jest bezcelo-

1 E. Potulicka, Teoretyczne podstawy neoliberalizmu a jego praktyka, [w:] E. Potulicka, J. Rutkowiak, Neoliberalne uwikłania edukacji, Oficyna Wydawnicza „Impuls”, Kraków 2010, s. 53.

2 E. Potulicka, Pytania o skutki neoliberalizmu. Aspekt jednostkowy, [w:] E. Potulicka, J. Rutkowiak, Neoliberalne uwikłania edukacji, Oficyna Wydawnicza „Impuls”, Kraków 2010, s. 315.

3 J. Baudrillard, Społeczeństwo konsumpcyjne, jego mity i struktury, Wyd. Sic!, Warszawa 2006, s. $46-47$.

4 D. Boaz, Libertarianizm, Zysk i S-ka, Poznań 2005, s. 30. 
we. Dlatego też jego „atomizacja”, polegająca na skupianiu się raczej na jednostce niż na społeczeństwie jako całości, prowadzi do zaniku sfery obywatelskiej, a wraz z nią również do zaniku demokracji. Niemożliwe jest utożsamianie ze sobą tych ontologii, tym bardziej, że różnią się one już w swoich podstawowych założeniach. Po ogólnych rozważaniach na tym polu, przejdę do głównego zagadnienia niniejszego artykułu, dotyczącego uczenia się i kondycji edukacyjnego środowiska pracy w określonym, polityczno-ekonomicznym kontekście.

\section{Demokracja w miejscu pracy? - o (nie)uczeniu się postaw obywatelskich przez pracowników współczesnych przedsiębiorstw}

Być może już na samym początku u niektórych czytelników kwestia poszukiwania praktyk czy postaw prodemokratycznych w miejscu pracy może budzić zdziwienie, a nawet i sprzeciw. W miejscu tym bowiem, podobnie jak w każdej instytucji formalnej, istnieje wyraźna struktura i hierarchiczny system zarządzania. Co więcej, obecnie miejsca pracy są pomyślane raczej tak, aby służyć ochronie i dalszej ekspansji neoliberalnej doktryny, niż pracującym w nim ludziom. Z punktu widzenia teorii krytycznej nie ma miejsc politycznie neutralnych, a w każdym środowisku obecne są pewne, będące w stałym konflikcie i nieustannie rywalizujące ze sobą dyskursy. Neoliberalizm, jako dominująca ideologia globalnego kapitalizmu, dostrzegalny jest w wielu sferach życia współczesnego człowieka. Najmocniej jednak zakorzeniony i uprawomocniony, ale i najdotkliwiej odczuwany jest w miejscu pracy. Tam, gdzie interes publiczny i prywatny powinien się łączyć. Jednak obecnie coraz częściej praca, która stanowi ważną część działalności ludzkiej, traci niestety swój etosowy wymiar. Pozostaje w ten sposób tylko towarem, działalnością, którą przelicza się na posiadane środki o wartości wymiernej, ekonomicznej. To sprawia, że środowisko takie w istocie może niekorzystnie wpływać na uczenie się wśród pracowników postaw prodemokratycznych i służyć raczej uczeniu się funkcjonowania według zasad neoliberalnego rynku. Z drugiej strony coraz bardziej popularna staje się tzw. ekonomia społeczna, jako przykład pewnej praktyki, ale odmiennej od tej spotykanej w "tradycyjnych" przedsiębiorstwach. W swoich założeniach, ukierunkowanych na realizację celów społecznych, zakłada funkcjonowanie według reguł bliższych raczej demokracji niż neoliberalizmowi, co mogłoby pozytywnie wpływać na organizowanie środowiska pracy w sposób korzystny dla samego procesu uczenia się postaw obywatelskich i zaangażowanych w życie społeczności praktyki. Ponadto, jak wiemy, zjawisko uczenia się dorosłych jest w swej istocie bardzo złożone i zależy od wielu czynników. Zarówno tych zewnętrznych, jak np. odgórne założenia polityczne czy systemy rynkowe, jak i tych wewnętrznych, takich jak np. negocjowanie znaczeń przez członków danej społeczności praktyki, wytwarzanie 
własnych systemów firmy, polityki wewnętrznej, itp. Stąd też podobnie w miejscu pracy, nie tylko zależy ono od samego sposobu organizacji środowiska edukacyjnego, czy przyjętego systemu edukacji formalnej, ale też np. od kultury wytwarzanej w obrębie zawodowych społeczności praktyki, będącej cennym źródłem czy wymiarem nieformalnego uczenia się $w$ danym środowisku pracy. Przy tym fenomen ten jest wynikiem nie tyle kumulowania się tych wszystkich czynników, ile raczej ich wzajemnego korespondowania ze sobą, bycia w procesie charakteryzującym się swoistą, unikatową dynamiką. Przy zastanawianiu się nad zjawiskiem uczenia się we współczesnych miejscach pracy, nasunęło mi się pytanie o to, jak istniejące $\mathrm{w}$ większości przedsiębiorstw warunki środowiska zawodowego, zaprojektowanego według neoliberalnej doktryny oraz wszechobecna (rynkowa) tzw. „kultura zysku” mogą utrudniać lub wręcz uniemożliwiać uczenie się prodemokratycznych postaw? A może przeciwnie, przejawiając się $\mathrm{w}$ formie oporu stawianego przez pracowników przedsiębiorstwa względem narzuconego im sposobu uczenia się funkcjonowania w zgodzie $\mathrm{z}$ neoliberalną doktryną, jak mogą wspierać uczenie się demokracji uczestniczącej w miejscu pracy? Gdyż to właśnie w wyniku tego rodzaju przymusu może przecież najszybciej dojść do nabywania postaw kontestacyjnych. Spróbuję teraz zastanowić się nieco dłużej nad najczęściej spotykanymi uwarunkowaniami środowisk uczenia się w miejscu pracy, czyli nad kondycją współczesnych przedsiębiorstw.

\section{Neoliberalny kontekst uczenia się we współczesnych miejscach pracy}

W większości współczesne przedsiębiorstwa to organizacje przedmiotowe o cechach totalitarnych, skierowane przeciw człowiekowi i działające według niedemokratycznych zasad. Zmierzają do celów sprzecznych z dobrem człowieka, a ich kierownicy posługują się przymusem, wymagając przy tym bezwarunkowej dyscypliny i posłuszeństwa. Taki typ organizacji osłabia odpowiedzialność, pomysłowość i aktywność jej członków, otępia i zniechęca, nierzadko doprowadzając ich do frustracji. W obszarze zarządzania stwierdza się narzucanie ludziom centralnych rozwiązań, czemu nie towarzyszą konsultacyjne rozmowy. Owocuje to decyzjami arbitralnymi, które z dialogiem w miejscu pracy jak i też poza nim, w lokalnej społeczności, nie mają nic wspólnego. Pracownicy postrzegani są jako producenci - maksymalnie wydajni, dyspozycyjni i niewolniczo oddani zatrudniającej ich korporacji, motywowani zewnętrznie, konkurencyjnie nastawieni wobec innych, egoistyczni, ekspansywni, ale zarazem wewnętrznie pokorni, pod groźbą niemożności spłacenia swoich kredytów bankowych. Neoliberalizm pogłębia charakterystyczny podział na rynku pracy i dystans społeczny między wysoko wykwalifikowanymi profesjonalistami i nisko wykwalifikowanymi producentami. Coraz częściej pracownicy są zmuszeni podjąć pracę poniżej swoich 
kwalifikacji. Oferuje się im kontrakty czasowe, które pozbawiają szans na stałe zatrudnienie. Zle warunki pracy, nagminne łamanie praw i despotyczne nastawienie pracodawcy sprawia, że miejsce pracy staje się dla współczesnego człowieka opresyjne. Jednostka zostaje obarczona odpowiedzialnością za swój los w danym przedsiębiorstwie, choć i tak na swój pobyt w nim nie ma zbyt wielkiego wpływu. Korporacjonizm wpływa też na kulturę nauczania i uczenia się kwalifikacji, niezbędnych do wykonywania zawodu. Wykształcenie staje się źródłem podnoszenia wartości pracy we współczesnej gospodarce, która wymaga ogólnych umiejętności analitycznych, zdolności rozumowania oraz innowacyjności. Można zdobyć je na uczelniach, ale im większa jest rola edukacji w tym osiąganiu awansu zawodowego, tym większe niebezpieczeństwo pogłębiania nierówności społecznych ${ }^{5}$. Celem edukacji będącej na usługach polityki neoliberalnej jest kształcenie siły roboczej, co przejawia się w okrojonych planach nauczania, przekazywaniu konkretnych i wąskich umiejętności, zamiast wiedzy. W ten sposób produkuje się rożnego rodzaju specjalistów, ekspertów (tzw. „fachidiotów”), którzy posiadają pewien zakres wiedzy w swojej wąskiej dziedzinie, ale kosztem wiedzy ogólnej, kontekstualnej na dany temat. Zjawisko to może powodować nie tylko negatywne skutki dla społeczeństwa i środowiska, ale nawet być źródłem poważnego zagrożenia dla ogółu ludzkości, w szerszej perspektywie. W dodatku można odnieść wrażenie, że niestety edukacja rozumiana jako nauczanie w miejscu pracy w ogóle nie służy rozwojowi pracowników i podniesieniu jakości ich życia, ale jest tylko narzędziem uprawomocniającym dominującą, neoliberalną kulturę. Zaprojektowana najczęściej jest tak, by służyć głównie celom organizacji, czyli stałemu pomnażaniu zysków przedsiębiorstwa. Podsumowując, nie sposób się nie zgodzić z tym, że „obecnie kształcenie redukuje się jedynie do powiększania kapitału ludzkiego", zajęcia kształceniowe do ćwiczeniowych szkoleń praktycznych, nierzadko z elementem ludycznym, etosowe potencjały ludzi do instrumentalnej sprawności człowieka optymistycznego i wydajnego producenta, sam zaś ideał ludzkiego współdziałania sprowadza się jedynie do zasad konkurencyjności" . Z k kolei innym, aczkolwiek nowym i obecnie coraz częściej obserwowanym trendem jest organizowanie współczesnych przedsiębiorstw według zasad ekonomii społecznej.

\footnotetext{
5 E. Potulicka, Pytania o skutki neoliberalizmu. Aspekt społeczny, [w:] E. Potulicka, J. Rutkowiak, Neoliberalne uwikłania edukacji, Oficyna Wydawnicza „Impuls”, Kraków 2010, s. 328.

6 J. Rutkowiak, Czy istnieje edukacyjny program ekonomii korporacyjnej?, [w:] E. Potulicka, J. Rutkowiak, Neoliberalne uwikłania edukacji, Oficyna Wydawnicza „Impuls”, Kraków 2010, s. 33.
} 


\section{Pomiędzy społeczeństwem a ekonomią - uczenie się $\mathrm{w}$ przedsiębiorstwach społecznie odpowiedzialnych}

Coraz częściej zwraca się uwagę na znaczenie odrodzenia się etosu ekonomii, której obowiązkiem jest służenie prawdzie i interesom światowej społeczności ${ }^{7}$, a postuluje się odejście od centralizacji, specjalizacji czy standaryzacji na rzecz różnorodności, elastyczności, czy twórczości w działaniuষ Przede wszystkim preferuje się organizacje podmiotowe zamiast przedmiotowych, czyli takie, które służą człowiekowi, a nie gdzie człowiek jest środkiem do celu i odnoszą się do jego współdziałania w zespole lub szerzej, w całym społeczeństwie. Organizacja dla człowieka dostosowana jest do jego fizycznych i psychicznych możliwości. Propaguje przyjazną kulturę pracowniczego współżycia, która polega na poszanowaniu godności człowieka. Włącza pracownika do procesu zarządzania. Oznacza to, w pewnym sensie, prymat człowieka w organizacji, co jednak może też powodować całkowitą identyfikację pracownika z zastanym porządkiem, pozbawiając go jakiejkolwiek dozy krytycyzmu. Wymienionym hasłom towarzyszą rozwiązania koncepcyjne w postaci np. przedsiębiorczości społecznej, która dotyczy podejmowania działalności innowacyjnej przez przedsiębiorstwo, ale jednocześnie próbuje przy tym zachowywać wartości istotne z punktu widzenia społeczeństwa. W literaturze istnieje wiele różnych definicji tego zagadnienia. Lidia Zbiegeń-Maciąg definiuje społeczną odpowiedzialność jako moralną odpowiedzialność firmy i zobowiązanie do rozliczania się przed społeczeństwem ze swojej działalności. Inna grupa definicji, jaka została stworzona przez międzynarodowe organizacje, takie jak np. Światowa Rada Biznesu ds. Zrównoważonego Rozwoju, przedstawia społeczną odpowiedzialność biznesu jako etyczne zachowanie przedsiębiorstwa wobec społeczeństwa. Polega ono na stałym zaangażowaniu biznesu w postępowanie etyczne i przyczynia się do ekonomicznego rozwoju, przy równoczesnym ulepszaniu życia pracowników i ich rodzin, jak również lokalnej społeczności i całego przedsiębiorstwa ${ }^{10}$. Najczęściej społeczna odpowiedzialność bywa jednak rozpatrywana w takich obszarach, jak: ekonomiczny, polegający na zdolności do tworzenia zysku, ale i polepszania wizerunku przedsiębiorstwa, wzrostu konkurencyjności i innowacyjności, kształtowania społecznej kultury organizacyjnej, wzrostu zaangażowania i motywacji pracowników, zainteresowaniu potencjalnych inwestorów, poszerzaniu swojego kręgu stałych i lojalnych

7 Ibidem, s. 30.

8 B. Kłusek-Wojciszke, M. Łosiewicz, Wiedza jako specyficzny zasób przedsiębiorstwa, [w:] Wspótczesne przedsiębiorstwo. Zasobowe czynniki sukcesu w konkurencyjnym otoczeniu, pod red. J. Frycy, J. Jaworskiego, Prace Naukowe Wyższej Szkoły Bankowej w Gdańsku, Gdańsk 2009, t. IV, s. 133-146.

9 L. Zbiegień-Maciąg, Etyka w zarządzaniu, PWN, Warszawa 1991, s. 48-49.

10 J. Nakonieczna, Spoteczna odpowiedzialność przedsiębiorstw międzynarodowych, Centrum Doradztwa i Informacji Difin Sp.z o.o, Warszawa 2008, s. 19. 
klientów, dobrych relacjach z dostawcami, tworzeniu pozytywnych relacji ze społecznością lokalną, np. wizerunek dobrego pracodawcy, wiarygodnego partnera, darczyńcy, itp. ${ }^{11}$; prawny, czyli prowadzenie działalności gospodarczej, zobowiązań podatkowych, ochrony środowiska, ochrony konsumenta, prawa pracy, zobowiązań biznesowych, dotyczący przejrzystości i jawności działalności przedsiębiorstwa, wiarygodności i zaufania do inicjatyw przedsiębiorstwa, zapewnienie rzetelności systemów rachunkowości i sprawozdawczości finansowej przedsiębiorstwa, rzetelne, terminowe wywiązywanie się ze zobowiązań finansowych, rzetelne wypełnianie i dotrzymywanie postanowień umów, zapewnienie stabilnej wspólpracy z interesariuszami zwiększenie atrakcyjności i zaufania potencjalnych inwestorów i instytucji finansowych; etyczny, który polega na dostrzeganiu skutków swojej działalności oraz ponoszeniu za nie odpowiedzialności, kierowaniu się dobrem ogółu, nawet za cenę utraty własnych korzyści; oraz obszar filantropijny, opierający się na działaniach charytatywnych czy umiejętności dzielenia się $\mathrm{z}$ innymi ${ }^{12}$. Interesujące jest to, że według założeń ekonomii społecznej istnieje duże prawdopodobieństwo, iż przedsiębiorstwo, które w sposób świadomy, zaplanowany i skoordynowany podejmuje działania społecznie odpowiedzialne, zyska zaufanie, które przełoży się w dłuższym okresie na kształtowanie efektywnych relacji z przedstawicielami otoczenia i lepsze warunki finansowe oraz odpowiednią pozycję na rynku ${ }^{13}$. Mimo to rezultaty takie, jak wzrost demokracji w miejscu pracy czy współpraca z lokalną społecznością oraz powstawanie poczucia wspólnoty i poprawa klimatu w firmie są ciągle bardzo trudne do zmierzenia, a rezultaty ekonomiczne wciąż są faworyzowane w stosun$\mathrm{ku}$ do nieekonomicznych. Rozumienie społecznej odpowiedzialności przez przedsiębiorstwa może być pojmowane w kategoriach szerokiego zakresu zobowiązań danej firmy, umiejscawiając ją w koncepcjach kształtowania społecznej strefy działalności. Jednak częściej widziana jest przez pryzmat najlepszego sposobu polepszania publicznego wizerunku, będąc częścią działań o charakterze marketingowym. Wciąż człowiek coraz częściej służy organizacji, organizacja coraz mniej ludziom, co znacznie komplikuje życie społeczne. Rezultaty procesu przedsiębiorczego są oceniane w sposób bardzo zawężony, na ogół w odniesieniu do jednej grupy docelowej. Nie uwzględnia się oddziaływania na innych (szerszych) poziomach, skutków funkcjonowania przedsiębiorstwa np. zewnętrznych, w których mieści się środowisko czy społeczeństwo. Niestety, w większości zasady społecznej odpowiedzialności są w opozycji do faktycznej ich realizacji. Największe znaczenie dla właścicieli badanych firm mają obszary ekonomiczny i prawny, mniejszą wagę przywiązują zaś do spraw etycznych. Społeczna odpo-

11 Ibidem, s. 54.

12 M. Rybak, Etyka menedżera - społeczna odpowiedzialność przedsiębiorstwa, PWN, Warszawa 2004 , s. $29-31$.

13 A. Sokołowska, Cechy społecznej odpowiedzialności małego przedsiębiorstwa w dobie kryzysu, [w:] Wspótczesne przedsiębiorstwo. Zasobowe czynniki sukcesu w konkurencyjnym otoczeniu, pod red. J. Frycy, J. Jaworskiego, Prace Naukowe Wyższej Szkoły Bankowej w Gdańsku, Gdańsk 2009, t. IV, s. 51-61. 
wiedzialność traktowana jest $\mathrm{w}$ badanych przedsiębiorstwach często $\mathrm{w}$ ograniczony sposób, tzn. bardziej jako narzędzie public relations, w realizacji krótkoterminowych wskaźników finansowych albo jako jednorazowa akcja charytatywna dla poprawy wizerunku, a nie jako celowa, racjonalna i wewnętrznie zintegrowana koncepcja ${ }^{14}$. W moich rozważaniach, mając na uwadze powiązania neoliberalizmu i edukacji, muszę przyznać, że niewątpliwie, o czym też przekonałam się dużo wcześniej prowadząc badania w miejscach pracy, neoliberalne założenia mają głównie wpływ na jakość środowiska edukacyjnego. Neoliberalizm, czy w ogóle jakiekolwiek inne założenia polityczne, bardzo silnie oddziałują na konkretne miejsca, tworząc w nich jakby ramy, w których toczy się wewnętrzne życie społeczne danej grupy pracowniczej. Widząc ten neoliberalny kontekst i mając jego świadomość nie można jednocześnie zapominać o specyficznej dynamice życia toczącego się wewnątrz każdej organizacji, jej kulturze, itp., gdyż czynniki te mają ogromny wpływ na jakość uczenia się. Zatem zamiast pytać o demokrację w miejscu pracy ulokowaną w odgórnych założeniach politycznych i systemach zarządzania, może należałoby jej raczej szukać w epizodycznych lub nawet jednorazowych kontekstach sytuacyjnych, podczas zwykłego pracowniczego partycypowania w miejscu pracy.

\section{Demokracja uczestnicząca zakorzeniona w codziennym życiu społecznym miejsca pracy}

Być może właśnie owa demokratyczność miejsca pracy, czy gotowość ludzi do zaangażowania w działalność zgodną z celami społecznymi, ukryta jest $\mathrm{w}$ tzw. „rzeczach małych”, wytwarzana poprzez uczestnictwo w codziennej praktyce zawodowej i obserwowalna za pośrednictwem pracowniczych interakcji? Może przejawia się ona bardziej w pewnych taktykach obronnych czy też tzw. strategiach przetrwania albo $w$ oddolnych inicjatywach podejmowanych przez zatrudnionych ludzi? Miejsce pracy, pomimo że jest swego rodzaju instytucją, w której dominuje narracja zgodna z polityką neoliberalną, nie determinuje ostatecznie życia pracowniczego. Człowiek mimo wszystko nie jest w swoim środowisku zawodowym tylko jego odbiorcą, biernym obserwatorem, który się uczy, jak dostosować się do środowiska, w którym funkcjonuje. Będąc jego ważnym „elementem" zmienia go, a nie tylko bezrefleksyjnie odtwarza pewne zastane wzorce. Bohaterami i twórcami każdej instytucji są właśnie działający tam ludzie. Przyjmując założenie, że ludzie nieustannie tworzą i współtworzą świat, w którym żyją, również ich świat społeczny istniejący w sferze zawodowej będzie podlegał nieustannym de- lub/i re-konstrukcjom $\mathrm{w}$ toku codziennych interakcji. Uczenie się roli zawodowej i kultury danej organizacji osadzone jest zawsze w kontekście, ale kontekst ten nie stanowi tutaj zastygłej struktury systemu neo-

14 Ibidem, s. 59. 
liberalnego. Moje doświadczenia badawcze pokazują, że nawet w warunkach bardzo ograniczonych dla uczenia się demokracji w miejscu pracy mogą mieć miejsce pewne praktyki włączające pracowników w życie organizacji. Przykładem są badania prowadzone $\mathrm{w}$ duńskim przedsiębiorstwie, gdzie mimo bardzo zhierarchizowanego sposobu zarządzania istniała spora przestrzeń do zagospodarowania dla wszystkich pracowników, zgodnie z ich własną wizją miejsca pracy. Oznacza to nie tyle skłonność do interpretowania kontekstów, w których człowiek żyje, ale wręcz wytwarzanie ich przez uczące się podmioty ${ }^{15}$. Najczęściej to właśnie praktyka życia codziennego, a nawet tylko względy pragmatyczne sprawiają, że człowiek jako podmiot ma w niej spore znaczenie. Nie tylko poznaje, ale i zmienia zastaną rzeczywistość. I w tym właśnie tkwi potencjał emancypacyjny jednostki. Stąd też problematyzacji może ulegać założenie jedynie o zdolności do reprodukcji właściwości kultury neoliberalnej. Mając na względzie przesłanki konstruktywistycznej filozofii, należy rozważyć i docenić rolę owych mikroświatów, gdyż kultura neoliberalna może być różnie odbierana. Postrzegana jako szansa na realizację własnych (prywatnych) interesów, czy też jako szansa na pogłębianie i modyfikowanie własnych doświadczeń, w wyniku czego następuje właśnie uczenie się zachowań kontestacyjnych i na przymus partycypacji w takim opresyjnym środowisku odpowiada się po prostu oporem. Stąd też uważam, że jakakolwiek zmiana zastanego porządku wydaje się być bardziej realna $\mathrm{w}$ formie samoorganizacji ludzi, stymulując przemiany oddolne, inicjatywy nieformalne, aktywność społeczności lokalnych czy indywidualnych działań obywatelskich, gdyż tylko realne doświadczenia ludzi znajdujących się w tych miejscach sprzyjają uczeniu się i zmianie społecznej. Do tego potrzebna, czy wręcz niezbędna jest zaangażowana edukacja. Nie chodzi więc zatem o całkowitą negację czy odrzucanie instytucji, jakimi są miejsca pracy, jako jednego z obszarów zmiany w rzeczywistości neoliberalnej i tym samym negowania faktu zrodzenia się w nich demokracji, lecz o akcentowanie działających w nich jednostek stanowiących $w$ istocie trzon tych środowisk. Oczywiście moje spostrzeżenia $w$ tej kwestii są bardzo świeże i potrzebują dalszego rozszerzenia problemu w formie danych empirycznych. Niemniej jednak, z punktu widzenia samej edukacji, jak też sposobu organizacji środowisk pracy istotne jest prowadzenie badań w obszarze uczenia się w miejscu pracy. Skoro każde uczenie odbywa się w warunkach społecznych, bardzo ważne jest zbadanie, jak warunki danego miejsca pracy wraz z jego życiem społecznym i kulturą oddziaływają na proces uczenia się. Instytucje czy przedsiębiorstwa zawsze zorganizowane są według pewnego, przyjętego odgórnie modelu, który jest pewnym kontekstem dla uczenia się. Stąd też badając miejsca pracy, powinno się zwracać uwagę na swego rodzaju dialog, czy nawet "grę" członków danej społeczności uczących się z narzuconymi ramami funkcjo-

15 J. Rutkowiak, Uczenie się w warunkach kultury neoliberalnej: kontestowanie jako wyzwanie dla teorii kształcenia, [w:] E. Potulicka, J. Rutkowiak, Neoliberalne uwikłania edukacji, Oficyna Wydawnicza „Impuls", Kraków 2010, s. 170. 
nowania w danej organizacji. Może zamiast pytać o to, czy możliwa jest demokracja w miejscu pracy, należałoby zadać pytanie, jak jest ona możliwa? Jest to też pytanie o kontekst uczenia się postaw zaangażowanych, obywatelskich, a więc też pytanie o uwarunkowania środowiska edukacyjnego, jakim jest miejsce pracy. Inaczej mówiąc, jest to po prostu pytanie o to, jak i w jakim stopniu dane miejsce pracy mogłoby się stać przestrzenią dla rozwijania postaw prodemokratycznych? Stosownych odpowiedzi na te pytania (wyzwania) mogą dostarczyć jedynie zaangażowane badania w środowisku pracy.

\section{Summary}

\section{Democracy and the workplace learning}

The general aim of the paper is to reflect on a relation between neoliberal, educational environment in the workplaces and possibilities to learn acting in accordance with democratic rules in this environment. Institutions or enterprises are always organized in a concrete, prevailing model, which constitutes a context of learning. Neo-liberalism as the global and dominant ideology is presented in many area of human's life. Although it is the deepest embedded and it is the strongest legitimized in the workplace where it 'serves' company's owners rather than employees. Because of design the today's workplaces frequently on the point of protection or further expansion of neoliberal doctrine, workers are just suffered by this ideology. This type of educational environment could have harmful influence on learning of democratic attitudes. On the other hand social economy becomes the most popular as an example of totally different practice than that encounter in traditional enterprises. The social economy claims activity according to democratic rules with its social goals in itself assumption rather than neo-liberal, economic goals. It could have a good influence on environment for learning of public spirit and it encourages to engage in community of practice inside the organization. Unfortunately The Corporate Social Responsibility (CSR) is seen merely as a form which improves of public relation between society and organization. In the same time it is only a part of market's promotion. However each type of learning is going on in social conditions. What means that we also should take into account inside conditions of educational environment in the workplace, which have a huge impact on whole process of learning. Authoress of the paper considers, how do occurred conditions in majority companies with their dominant 'profit's culture' be able to make impossible, to make difficult or contrariwise - how do they support learning of democratic attitudes in nowadays workplaces? 